\title{
MANAGEMENT OF OPERATIONAL AND INVESTMENT ACTIVITY OF LOCAL GOVERNMENTS IN POLAND
}

\author{
Justyna ŁUKOMSKA-SZAREK \\ Czestochowa University of Technology, Czestochowa; justyna.lukomska-szarek@wz.pcz.pl, \\ ORCID: 0000-0001-5521-9294
}

\begin{abstract}
Purpose: Management in local governments always depends on the budget possibilities of these entities. Local governments are obliged to perform many public tasks, but they do not always have adequate financial resources. The basic aim of the paper is to examine the management of the operational and investment activity of LGUs in Poland. Design/methodology/approach: The main objective of the study is to systematize the basic concepts and analytical indicators used to quantify the level of operational and investment activity of local governments. The research period covered the years 2012-2017. The paper attempts to verify the main research hypothesis: "The management of operating activity and investments in LGUs in Poland depends on the financial resources generated by these entities at the current and property level." The main research hypothesis is complemented by 4 detailed hypotheses. The analysis covered in particular 7 groups of indices.
\end{abstract}

Findings: The conducted preliminary and vertical analysis of the budget economy made it possible to indicate the major trends and directions of changes in incomes, budget expenditures and the financial result of the budgets of LGUs at the operational and property level in 20122017. Incomes and budget expenditures escalated over the period studied, although in 20152016, incomes grew faster than expenditures and, consequently, the budgets of LGUs in Poland showed a budget surplus. Management of operational and investment activity of LGUs is determined, among others, by their financial possibilities and development potential. Unfortunately, after 2015, both the operational and total potential for the development decreased in the units studied. In 2016, the units implemented very moderate investment policies, even though their capability of self-financing was quite high. The revival of the investment activity occurred in 2017.

Research limitations/implications: It is possible to continue the research in the following years.

Practical implications: It is possible use of research by public sector entities.

Social implications: Information on managing operational and investment activities of local government units in Poland.

Originality/value: A synthetic approach to the management of operational and investment activities of LGUs in Poland in a selected period of time.

Keywords: management, operational activity, investment activity, operational and total capacity for development, financial independence, local government.

Category of the paper: Research paper; case study. 


\section{Introduction}

The budget economy is an integral system in which decisions and processes that govern the management of public financial resources on many organizational levels of the public sector permeate each other (Sołtyk, and Dębowska-Sołtyk, 2016, p. 33). The financial system of local government units (LGUs) includes collecting and organizing financial resources and spending them (Sawicka, 2013, p. 288). Administration of public funds within this system means their use and management in the well-understood interest of the local government community (Lukomska-Szarek, et. al., 2018, p. 50). Management of the activities of LGUs is aimed at implementation of public tasks of operational and investment nature. The activities conducted by LGUs are determined by the rational allocation of limited property and capital resources at their disposal. Therefore, it should be noted that an inherent element of management of LGUs activity is appropriate management of their finances, which is not based on the profit criterion, but its objective should be to strive for the effective use of public funds adequately to the initiatives and activities both at the operational and investment levels (Król, 2016, p. 47). The primary objective in the process of financial management should be to maximize the benefits of the resources and to minimize the losses and risks associated with the performed activities, which particularly concerns development projects, where the benefits and costs are usually spread over time (Dylewski, et.al., 2006, p. 103). Management of public funds requires from LGUs to implement many changes in resource management, especially in recognition of the needs of inhabitants, adjustment of expenditures to these needs, and consequently, budget planning and implementation (Kożuch, 2012, p. 101). Current expenditures are allocated to the functioning of the local government and allow for the maintenance and operation of the existing infrastructure, while property expenditures are almost entirely used for the implementation of investment projects. Therefore, this paper discusses the management of activities of LGUs at the operational and investment levels and focuses on the financial aspects determining this activity.

\section{Methodology and data}

The basic aim of the paper is to examine the management of the operational and investment activity of LGUs in Poland. The central aspect of the research is the assessment of the impact of financial conditions of the surveyed entities on their current and property activity. The paper attempts to verify the main research hypothesis: The management of operating activity and investments in LGUs in Poland depends on the financial resources generated by these entities at the current and property level. The main research hypothesis is complemented by the 
following specific hypotheses: 1) Development of a surplus on the operational level complemented by property incomes in LGUs constitutes the basis of the unit's development potential and allows for stimulating investment activity; 2) The increase in the tasks of LGUs at the current (operating) level and the transfer of special-purpose subsidies from the state budget to finance these tasks leads to the reduction of financial independence in terms of generating internal incomes in gminas and towns with powiat status; 3) The slowdown in the investment activity of LGUs in Poland causes reduction of debt and smaller opportunities to obtain development subsidies and external funds; 4) Capital investments are of marginal importance for investment activity, whereas tangible investments in fixed assets prevail.

In order to verify the main research hypothesis and specific hypotheses, the study attempted to perform the ratio analysis of activities of LGUs in Poland at the operational and property level, as well as with the division into particular unit types. In this respect, an ex-post analysis was conducted based on historical data in a dynamic perspective, since the research concerned the years 2012-2017, allowing for the evaluation of the rate and trends of changes in the economic quantities studied. The analysis covered in particular the following indices: 1) indices of percentage structure of incomes and expenditures at the current and property levels; 2) level of financial result; 3) share of investments in fixed assets in total expenditures; 4) level of financial independence, defined as a share of own income in total income; 5) level of selffinancing, measured as a share of operating surplus and property income in property expenditures; 6) operational capacity for development, constituting a share of operating surplus

in current income and 7) total capacity for development, calculated as a share of operating surplus and property income in total income. The empirical material was prepared based on the data from reports on the execution of the budget of LGUs in Poland, studies by the Ministry of Finance and data from Regional Accounting Chambers. It should be emphasized that 16 voivodeship, 314 powiats (powiats are principal units of territorial division in Poland of the second level) and 2,478 gminas (including 66 cities with powiat status) operated in Poland in 2017.

\section{Results and Discussion}

\subsection{Vertical analysis of the activity at the operational and investment level of LGUs}

First and foremost, a preliminary analysis of activities of LGUs should be carried out, consisting in the evaluation of expenditures, incomes and the financial result of the budget. Table 1 presents a quantitative summary of the development of the indicated economic values over the period studied. These data lead to the conclusion that both budget expenditures and incomes were steadily increasing in 2012-2017. The activity conducted by LGUs in 2012 
required financial outlays of PLN 180.5 billion, and PLN 230.2 billion in 2017, which represents an increase of $25.65 \%$. In the period of the six years studied, the largest level of tasks performed was observed in gminas, with their expenditures ranging from PLN 78.5 to 112 billion, followed by towns with powiat status (PLN 22.4-25.4 billion) and powiats (PLN 51.1-63.2 billion). Dynamic growth of budget expenditures was observed in the entities studied: only voivodeships whose expenditures were at the level of PLN 12.6-18.2 billion were characterized by progress in 2012-2014 and 2017. It should also be noted that LGUs in total generated, except the years 2015-2016, lower budget incomes, which were insufficient to cover the executed budget tasks, which resulted in a budget deficit of PLN 3.1 billion in 2012 and PLN 0.3 billion in 2017. In order to identify the main determinants that influenced the situation presented above, it is justified to conduct a detailed analysis of the tasks performed by LGUs at the operational and investment levels. Table 1 presents also incomes, expenditures and financial results of the budgets with division into operating and property activities of particular types of LGUs. Analysis of such data leads to the conclusion that LGUs generated an operating surplus in each of the audited years, which oscillated around PLN 11.6-21.1 billion on average. The ability to develop long-term surpluses impacts on the pace of development processes in LGUs.

Table 1.

Revenues, expenditures and financial result of operating and investment activities of $L G U S$

\begin{tabular}{|c|c|c|c|c|c|c|c|c|c|c|c|c|c|c|}
\hline \multirow{3}{*}{ 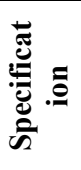 } & \multirow{3}{*}{ Year } & \multicolumn{5}{|c|}{$\begin{array}{c}\begin{array}{c}\text { Operating (current) } \\
\text { activities }\end{array} \\
\end{array}$} & \multicolumn{5}{|c|}{$\begin{array}{c}\text { Investment (property) activities } \\
\text { [in billion PLN] }\end{array}$} & \multicolumn{3}{|c|}{$\begin{array}{l}\text { Total activities of budget } \\
\text { [in billion PLN] }\end{array}$} \\
\hline & & \multicolumn{2}{|c|}{ revenues } & \multicolumn{2}{|c|}{ expenditure } & \multirow{2}{*}{$\begin{array}{l}\text { operat } \\
\text { ing } \\
\text { result }\end{array}$} & \multicolumn{2}{|c|}{ revenues } & \multicolumn{2}{|c|}{ expenditures } & \multirow{2}{*}{$\begin{array}{l}\text { property } \\
\text { result }\end{array}$} & \multirow{2}{*}{$\begin{array}{l}\text { revenue } \\
\mathrm{s}\end{array}$} & \multirow{2}{*}{$\begin{array}{l}\text { expendit } \\
\text { ures }\end{array}$} & \multirow{2}{*}{$\begin{array}{l}\text { financial } \\
\text { result }\end{array}$} \\
\hline & & $\begin{array}{l}\text { billion } \\
\text { PLN }\end{array}$ & $\begin{array}{l}\% \text { in } \\
\text { total }\end{array}$ & $\begin{array}{l}\text { billion } \\
\text { PLN }\end{array}$ & $\begin{array}{l}\% \text { in } \\
\text { total }\end{array}$ & & $\begin{array}{l}\text { billion } \\
\text { PLN }\end{array}$ & $\begin{array}{l}\% \text { in } \\
\text { total }\end{array}$ & $\begin{array}{l}\text { billion } \\
\text { PLN }\end{array}$ & $\begin{array}{l}\% \text { in } \\
\text { total }\end{array}$ & & & & \\
\hline \multirow{6}{*}{ 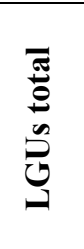 } & 2012 & 156.5 & 88.2 & 144.9 & 80.3 & 11.6 & 20.9 & 11.8 & 38.4 & 21.3 & -17.5 & 177.4 & 180.5 & -3.1 \\
\hline & 2013 & 163.1 & 88.9 & 148.9 & 81.0 & 14.2 & 20.4 & 11.1 & 34.9 & 19.0 & -14.5 & 183.5 & 183.8 & -0.3 \\
\hline & 2014 & 171.8 & 88.4 & 155.4 & 79.0 & 16.4 & 22.5 & 11.6 & 41.3 & 21.0 & -18.8 & 194.3 & 196.7 & -2.4 \\
\hline & 2015 & 176.1 & 88.5 & 157.9 & 80.4 & 18.2 & 22.9 & 11.5 & 38.5 & 19.6 & -15.6 & 199 & 196.4 & 2.6 \\
\hline & 2016 & 200.7 & 93.9 & 180.3 & 87.5 & 20.4 & 13 & 6.1 & 25.8 & 12.5 & -12.8 & 213.7 & 206 & 7.7 \\
\hline & 2017 & 216.1 & 94.0 & 195 & 84.7 & 21.1 & 13.8 & 6.0 & 35.2 & 15.3 & -21.4 & 229.9 & 230.2 & -0.3 \\
\hline \multirow{6}{*}{ 兽 } & 2012 & 70.6 & 90 & 65.3 & 83.2 & 5.3 & 7.8 & 10 & 13.2 & 16.8 & -5.4 & 78.4 & 78.5 & -0.1 \\
\hline & 2013 & 73.6 & 92.0 & 67.3 & 84.7 & 6.3 & 6.4 & 8.0 & 12.1 & 15.3 & -5.7 & 80 & 79.4 & 0.6 \\
\hline & 2014 & 77.7 & 91.9 & 70.6 & 83 & 7.1 & 6.8 & 8.1 & 14.5 & 17 & -7.7 & 84.5 & 85 & -0.5 \\
\hline & 2015 & 80.2 & 91.5 & 71.4 & 83.1 & 8.8 & 7.5 & 8.5 & 14.5 & 16.9 & -7 & 87.7 & 85.9 & 1.8 \\
\hline & 2016 & 97.6 & 95.9 & 87.2 & 88.8 & 10.4 & 4.2 & 4.1 & 11 & 11.2 & -6.8 & 101.8 & 98.2 & 3.6 \\
\hline & 2017 & 106 & 95.3 & 95.6 & 85.4 & 10.4 & 5.2 & 4.7 & 16.4 & 14.6 & -11.2 & 111.2 & 112 & -0.8 \\
\hline \multirow{6}{*}{$\begin{array}{l}0 \\
0 \\
0\end{array}$} & 2012 & 43.2 & 87.6 & 40.9 & 80.1 & 2.3 & 6.1 & 12.4 & 10.2 & 19.9 & -4.1 & 49.3 & 51.1 & -1.8 \\
\hline & 2013 & 45.9 & 88.3 & 42.7 & 80.9 & 3.2 & 6.1 & 11.7 & 10.1 & 19.1 & -4 & 52 & 52.8 & -0.8 \\
\hline & 2014 & 48.1 & 88.3 & 44.5 & 79.1 & 3.6 & 6.4 & 11.7 & 11.7 & 20.9 & -5.3 & 54.5 & 56.2 & -1.7 \\
\hline & 2015 & 50.1 & 89.0 & 46.4 & 81.5 & 3.7 & 6.2 & 11.0 & 10.5 & 18.5 & -4.3 & 56.3 & 56.9 & -0.6 \\
\hline & 2016 & 55.8 & 93.5 & 51.3 & 88.1 & 4.5 & 3.9 & 6.5 & 6.9 & 11.9 & -3 & 59.7 & 58.2 & 1.5 \\
\hline & 2017 & 59.7 & 94.8 & 54.8 & 86.7 & 4.9 & 3.3 & 5.2 & 8.4 & 13.3 & -5.1 & 63 & 63.2 & -0.2 \\
\hline \multirow{6}{*}{ : } & 2012 & 20.7 & 92.2 & 19.6 & 87.5 & 1.1 & 1.8 & 7.8 & 2.8 & 12.5 & -1 & 22.5 & 22.4 & 0.1 \\
\hline & 2013 & 21.3 & 92.4 & 20 & 87.5 & 1.3 & 1.8 & 7.6 & 2.9 & 12.5 & -1.1 & 23.1 & 22.9 & 0.2 \\
\hline & 2014 & 21.8 & 91.6 & 20.3 & 85.3 & 1.5 & 2 & 8.4 & 3.5 & 14.7 & -1.5 & 23.8 & 23.8 & 0 \\
\hline & 2015 & 21.6 & 91.3 & 20 & 85.4 & 1.6 & 2.1 & 8.7 & 3.4 & 14.6 & -1.3 & 23.7 & 23.4 & 0.3 \\
\hline & 2016 & 22.3 & 93.4 & 20.3 & 87.1 & 2 & 1.6 & 6.6 & 3 & 12.9 & -1.4 & 23.9 & 23.3 & 0.6 \\
\hline & 2017 & 23.3 & 91.9 & 21.7 & 84.9 & 1.6 & 2.1 & 8.1 & 4.1 & 16.1 & -2 & 25.38 & 25.36 & 0.02 \\
\hline
\end{tabular}


Cont. table 1.

\begin{tabular}{|c|c|c|c|c|c|c|c|c|c|c|c|c|c|c|}
\hline \multirow{6}{*}{ 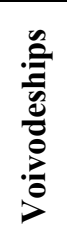 } & 2012 & 11.5 & 75.7 & 9.8 & 62.2 & 1.7 & 3.7 & 24.3 & 6 & 37.8 & -2.3 & 15.2 & 15.8 & 0.6 \\
\hline & 2013 & 11.5 & 71.7 & 9.9 & 60.3 & 1.6 & 4.6 & 28.3 & 6.6 & 39.7 & -2 & 16.1 & 16.5 & -0.4 \\
\hline & 2014 & 11.9 & 67.4 & 10.4 & 57.0 & 1.5 & 5.8 & 32.6 & 7.8 & 43.0 & -2 & 17.7 & 18.2 & -0.5 \\
\hline & 2015 & 11.5 & 67.1 & 9.4 & 54.9 & 2.1 & 5.6 & 32.9 & 7.8 & 45.1 & -2.2 & 17.1 & 17.2 & -0.1 \\
\hline & 2016 & 11.2 & 83.0 & 9.3 & 73.8 & 1.9 & 2.3 & 17.0 & 3.3 & 26.2 & -1 & 13.5 & 12.6 & 0.9 \\
\hline & 2017 & 12.3 & 83.6 & 10 & 69.8 & 2.3 & 2.4 & 16.4 & 4.3 & 30.2 & -1.9 & 14.7 & 14.3 & 0.4 \\
\hline
\end{tabular}

Own elaboration based on data form Ministry of Finance.

The operating result determines the level of current incomes available to local governments after financing obligatory current expenditure and debt service costs. Therefore, it allows for predicting the possibility of financing investment expenditures or the return of repayable instruments previously used for this purpose (Satoła 2015, p. 120). A negative result on property activity indicates the active investment activity of LGUs, although its slowdown is noticeable, especially in 2015-2016. The entities studied have been struggling with the limited potential of generating own funds for investment projects for years. Consequently, while managing the operational activity, LGUs aim to develop the highest possible operating surplus, which increased by $96.2 \%$ (from PLN 5.3 to 10.4 billion) in gmina government units, by $113 \%$ (from PLN 2.3 to 4.9 billion) in towns with powiat status, by only $50 \%$ in powiats and by $17.6 \%$ in voivodeships. The decreasing share of property income and high demand of LGUs for investments was possible due to the savings on the operational level, but also due to loans and borrowings obtained. Among the particular types of LGUs, the highest investment expenditures were incurred by gminas (PLN 11-16.4 billion) and towns with powiat status (PLN 6.9-11.7 billion), although a significant slowdown in investment activity was recorded in 2016 . The voivodeships invested at the level of PLN 3.3 billion, whereas powiats - at the level of PLN 3 billion. A broader picture of the generated financial resources and their allocation at the operational and investment levels is provided by the vertical analysis of the budget economy, which is aimed at the assessment of the percentage structure of individual components of local government units' budgets in Poland. In this respect, Table 1 presents the share of income and current and property expenditures in total. The structure of budget incomes and expenditures of LGUs in total was dominated by current incomes and expenditures. Current incomes oscillated between $88.2 \%$ and $94 \%$, with a noticeable upward trend in 2015-2017. The lowest current income was generated by voivodeships, with a visible regression from $75.7 \%$ in 2012 to $67.1 \%$ in 2015 and about 83\% in 2016-2017. Furthermore, current expenditures in 2012-2017 were maintained at a very similar level of $79-81 \%$, whereas they reached $87.5 \%$ in 2016 and $84.7 \%$ in 2017. 


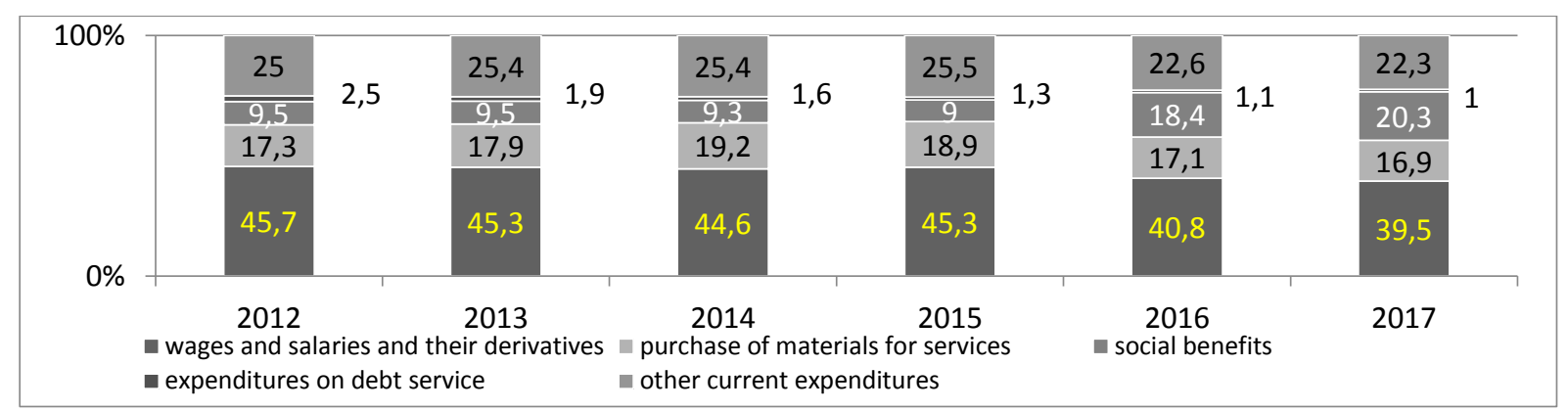

Figure 1. Structure of current expenditure of LGUs. Own elaboration based on data from Ministry of Finance.

Fig. 1 illustrates the division of individual types of tasks performed by LGUs at the operational level with the respective percentages of budget expenditures. The largest share was found for remunerations and their derivatives for local government employees (which in the years 2012-2015 were 45\%, whereas in 2016-2017, they were around 40\%) followed by purchases of goods and services between $16.9-19.2 \%$. The 500+ family programme introduced by the Polish government had a significant impact on the change in the structure of current expenditure in 2016-2017. Social benefits, which in previous years accounted for ca. 9\% of total current expenditure (PLN 14 billion), amounted to 18.4\% (PLN 33.1 billion) and 20.3\% (PLN 39.6 billion) in the last two years, respectively. The noticeable progress in financing social benefits after 2017 is continued, with e.g. school kit programme 300+ introduced in 2018, and a 500+ benefit granted to families for every child from July 2019, regardless of the income threshold in force in previous years. In the period studied, the most significant part of the operational activity of LGUs was financed by transfer incomes from the state budget, i.e. from special-purpose subsidies for current tasks and from general subsidies, as illustrated by Fig. 2 . The percentage structure index for general subsidies was characterized by regression from $32.2 \%$ to $25 \%$ of total current incomes. On the other hand, the largest growth was observed in targeted subsidies, in 2012-2015 they ranged between 15.4 and 16.4\%, and in 2016-2017 they amounted to $22.7-24.8 \%$ of current incomes. This progression was observed mainly due to the fact that funds for social benefit 500+ were transferred from the state budget to LGUs (gminas and towns with powiat status). Other income groups did not show a high amplitude of fluctuations.

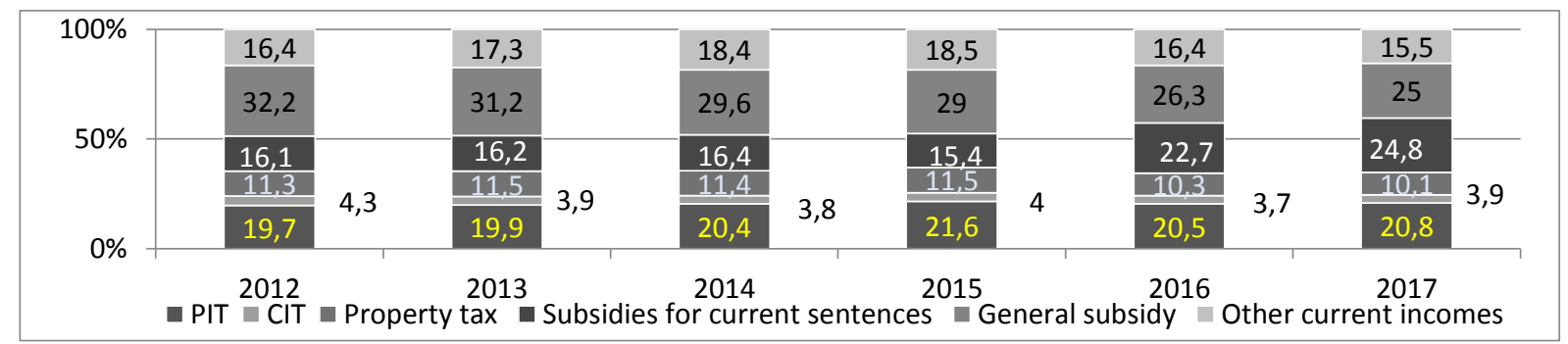

Figure 2. Structure of current revenues of LGUs. Own elaboration based on data from Ministry of Finance. 
Unfortunately, the increase in subsidies for current tasks adversely affected the degree of financial independence in terms of generating own incomes of gminas and towns with powiat status, especially in 2016-2017. The verification of the second specific hypothesis allows for the assessment of the data presented in Fig. 3.

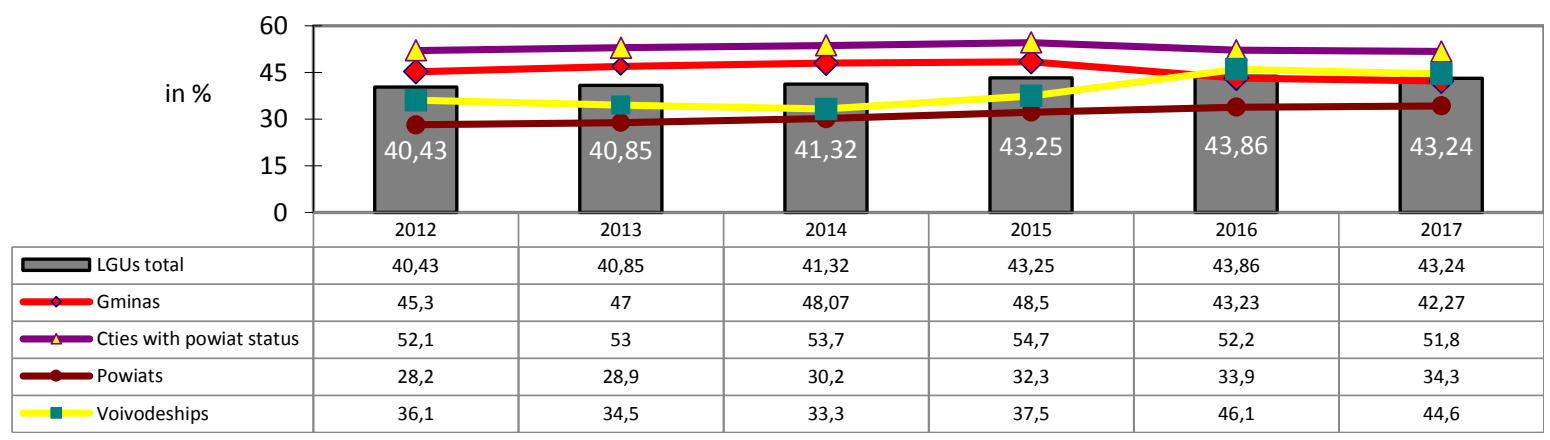

Figure 3. Degree of financial autonomy in generating own income of LGUs. Own elaboration based on data from Ministry of Finance.

It can be indicated that the category of own income potential includes mostly stable sources of own incomes of LGUs, which provide cyclic and very predictable revenues to the local government budget and do not expire after a short time. When assessing LGUs in this area, it can be stressed that they were distinguished by financial independence at the level of 40.43$43.86 \%$. The increase in financial support from the state budget contributed to a reduction in the financial independence of gminas from $48.5 \%$ in 2015 to $42.27 \%$ in 2017 . Towns with powiat status were characterized by the greatest potential to generate own income at the level of $54.7 \%$ in 2015 , whereas in $2016-2017$, it was reduced to $52.2-51.8 \%$. Since 2014 , the financial independence increased in powiats (from 30.2-34.3\%) and voivodships (from 33.3$46.1 \%$, although this was due to the good economic situation, high economic growth, tightening of the tax system and low unemployment. A high share of own income in total income provides the basis for local development policies by supporting long-term decisionmaking regarding the level of investments, loans and borrowings (Brzozowska, et al. 2017, p. 93; Kornberger-Sokołowska, 2012, p. 17). A similar view was presented by Jastrzębska, who emphasized that greater financial independence of LGUs was fostered by shaping their own budget policies, which constitute the basis for their development, and by better level of meeting the needs of their inhabitants (Jastrzębska, 2012, p. 54). The opportunities for satisfying the needs of the society in terms of implementation of development tasks have a significant impact on improving the quality of life of the inhabitants (Stanny, and Strzelczyk 2018, p. 87). The share of investment expenditures in the total expenditures of LGUs plays a significant role in the assessment of expenditure independence. Investment expenditures are those determined by LGUs themselves (Surówka, 2013, p.114). Investment (property) expenditures in LGUs, covering two groups of investments, i.e. tangible investments (in fixed assets) and capital investments, ranged from 19 to $21.3 \%$ of total expenditures in 2012-2015 (Table 1). The collapse of the growth trend was recorded in 2016, since the analysed indicator decreased 
to $12.5 \%$ and it should be stressed that it was in this period that particular types of LGUs recorded the lowest investment outlays. Although a reverse tendency was observed in 2017 with respect to the declining trend (as the analysed indicator for LGUs in total amounted to $15.3 \%$ ), these units did not return to high investment activity. The greatest slowdown in investment activity took place in gminas and towns with powiat status. An impressive share of property expenditures was recorded by voivodships (35.9-45.1\% in 2012-2015, 26.2\% in 2016 and $30.2 \%$ in 2017). Property investments are of key importance to property expenditures. Their share in total expenditures is presented in Fig. 4, with the highest measures recorded in $2014(20.3 \%)$ and the lowest in $2016(11.8 \%)$.

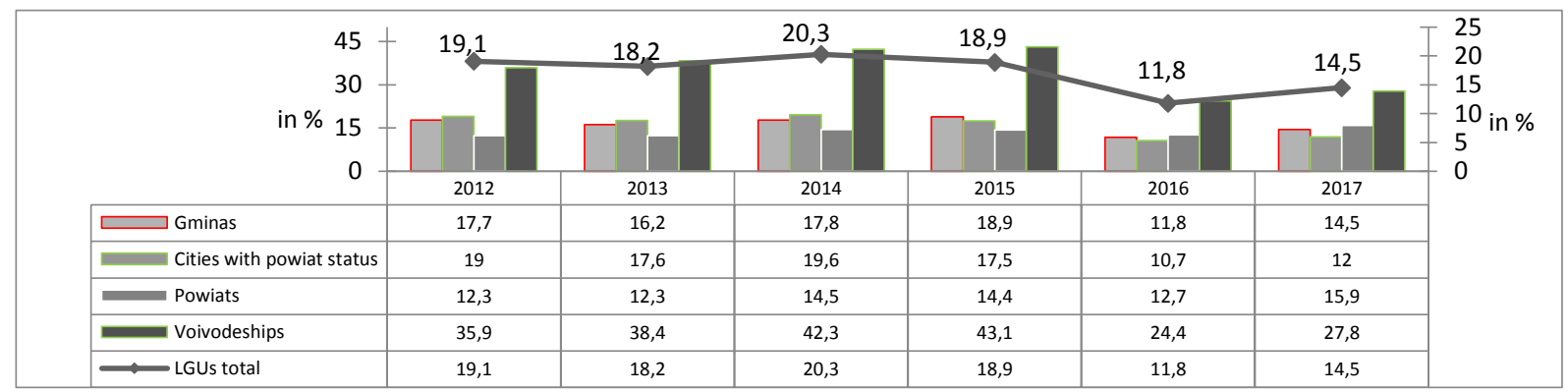

Figure 4. Share of investment expenditures in fixed assets in total expenditures of LGUs. Own elaboration based on data from Ministry of Finance.

Comparison of the data presented in Table 1 and in Fig. 4 leads to the conclusion that capital investments are of minor importance in terms of investment activity, whereas the investments in fixed assets are dominating, which allows for verification of the fourth specific hypothesis. The level of investments in fixed assets was 11.8 to $18.9 \%$ in gminas, 10.7 to $19.6 \%$ in towns with powiat status, 12.3 to $15.9 \%$ in powiats, and 24.4 to $43.1 \%$ in voivodeships. This was due to the relatively high operating surplus, but also to the gradual reduction of the debt of LGUs. This is illustrated by the data presented in Tables 1 and Fig. 1. The share of expenditure on debt service decreased from $2.5 \%$ in 2012 to $1 \%$ of total expenditures in 2017 . It should also be pointed out here that the obligatory introduction of new legal solutions for monitoring of debt in LGUs (i.e. individual debt ratio) led to its partial reduction. However, a worrying trend is a noticeable regression in property income in 2016-2017, which accounted for $6 \%$ compared to over $11 \%$ in previous years. It should be stressed that the operating surplus and the property income constitute the so-called 'free resources', which is the source of investment financing. Therefore, if the property income is characterised by regression, the development potential of LGUs is also decreasing. The main determinant of the decrease (by almost half) of property income after 2016 was the fact of obtaining a smaller number of subsidies for investment tasks, which is confirmed by the data presented in Fig. 3. 


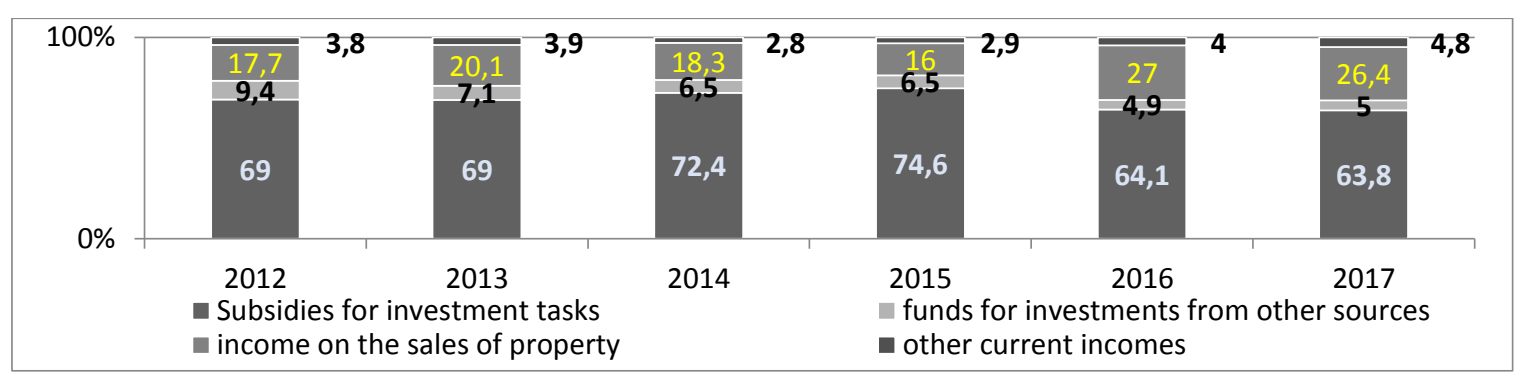

Figure 5. Structure of property revenue of LGUs. Own elaboration based on data from Ministry of Finance.

The escalation of the share of subsidies in total property income in $2012-2015$ from $69 \%$ to $74.6 \%$ was inhibited in 2016, when they accounted for 64.1\%, and in $2017(63.8 \%)$. Furthermore, funds for investments obtained from other sources decreased from $9.4 \%$ of property income to ca. 5\% in 2016-2017. This is particularly noticeable in the last two years, when LGUs decided to sell their properties to a greater extent. Incomes of this type accounted for ca. $27 \%$ of property income, compared to $16-20 \%$ in $2012-2015$. The research conducted in this area allows for the verification of the third specific hypothesis. In conclusion, the collapse of the growing trend of property revenue in the structure of total revenue occurred at all levels of LGUs after 2015, whereas the simultaneous increase in current income within the framework of special-purpose subsidies from the state budget caused a very unfavourable situation in terms of generating funds for development activities, consequently leading to the greatest slowdown in investment activity of these entities in Poland observed in recent years.

\subsection{Analysis of operational and total capacity for development and self-financing capacity of LGUs}

The last area of the ratio analysis of the budget economy of LGUs is the assessment of their development potential and self-financing capacity, which will allow for the verification of the first specific hypothesis. In this respect, the financial capacity of LGUs to generate free funds from the operating margin should be assessed in the first place. A summary of the individual indices is presented in Table 2. Slower investment activity, increased operating margin, and reduced debt resulted in an increased self-financing capacity of LGUs in Poland, especially in 2014-2016. The level of self-financing was the highest in gminas (264.7\% in 2017), whereas the lowest level was found in voivodeships and towns with powiat status, although it still oscillated around $100 \%$.

Table 2.

Operational and total capacity for development and self-financing index of LGUs [in \%]

\begin{tabular}{|c|c|r|r|r|r|r|r|}
\hline \multicolumn{2}{|l|}{ Specification } & $\mathbf{2 0 1 2}$ & $\mathbf{2 0 1 3}$ & $\mathbf{2 0 1 4}$ & $\mathbf{2 0 1 5}$ & $\mathbf{2 0 1 6}$ & $\mathbf{2 0 1 7}$ \\
\hline \multirow{3}{*}{ LGUs total } & WOR & 7.4 & 8.7 & 9.5 & 10.3 & 10.2 & 9.8 \\
\cline { 2 - 7 } & WORC & 18.3 & 18.9 & 20.0 & 20.7 & 15.6 & 15.2 \\
\cline { 2 - 7 } & Self-financing index & 111 & 130.3 & 106.1 & 120.2 & 151.8 & 146.1 \\
\hline \multirow{3}{*}{ Gminas } & WOR & 7.5 & 8.6 & 9.1 & 11.0 & 10.7 & 9.8 \\
\cline { 2 - 7 } & WORC & 16.7 & 15.9 & 16.4 & 18.6 & 14.3 & 14.0 \\
\cline { 2 - 7 } & Self-financing index & 130.3 & 190.2 & 114.3 & 148.1 & 180.9 & 264.7 \\
\hline
\end{tabular}


Cont. table 2.

\begin{tabular}{|c|c|r|r|r|r|r|r|}
\hline \multirow{2}{*}{$\begin{array}{c}\text { Cities with powiat } \\
\text { status }\end{array}$} & WOR & 5.3 & 7.0 & 7.5 & 7.4 & 8.1 & 8.2 \\
\cline { 2 - 7 } & WORC & 17.0 & 17.9 & 18.3 & 17.6 & 14.1 & 13.0 \\
\cline { 2 - 7 } & Self-financing index & 95.6 & 100.9 & 96.1 & 101.4 & 139.3 & 101.1 \\
\hline \multirow{3}{*}{\begin{tabular}{c} 
Powiats \\
\cline { 2 - 7 }
\end{tabular}} & WOR & 5.3 & 6.1 & 6.9 & 7.4 & 9.0 & 6.9 \\
\cline { 2 - 7 } & WORC & 12.9 & 13.4 & 14.7 & 15.6 & 15.1 & 14.5 \\
\hline \multirow{3}{*}{\begin{tabular}{l} 
Voivodeships \\
\cline { 2 - 7 }
\end{tabular}} & WOR & 127.5 & 132.6 & 116.2 & 129 & 149.6 & 109.9 \\
\cline { 2 - 7 } & WORC & 35.5 & 38.5 & 41.2 & 45.0 & 31.1 & 32.0 \\
\cline { 2 - 7 } & Self-financing index & 127.5 & 132.6 & 116.2 & 129 & 149.6 & 109.9 \\
\hline
\end{tabular}

Own elaboration based on data from table 1.

Until 2015, LGUs in total in Poland had been characterized by the progression of the total capacity for development, from 18.3 to $20.7 \%$. In 2016, there was a decline in the growing trend, with this indicator accounting for $15.6 \%$, whereas in 2017 , it was about $15.2 \%$. Unfortunately, most of the units studied showed a sharp decrease in both operational and total development capacity. This was mainly due to lower inflows from property income, especially from subsidies for investment activities. Unfortunately, the reduction in the operational and total development capacity and the accumulation of free funds from self-financing adversely affected the investment activities of the units studied.

\section{Summary}

In conclusion, the research conducted based on the selected group of indices allowed for verification of both the main and specific hypotheses. The conducted preliminary and vertical analysis of the budget economy made it possible to indicate the major trends and directions of changes in incomes, budget expenditures and the financial result of the budgets of LGUs at the operational and property level in 2012-2017. They lead to the conclusion that both incomes and budget expenditures escalated over the period studied, although in 2015-2016, incomes grew faster than expenditures and, consequently, the budgets of LGUs in Poland showed a budget surplus. Unfortunately, this period was also characterized by a very large slowdown in investment activity and accumulation of free funds within the self-financing. Local governments also generated a relatively low property income, whereas the increase in specialpurpose subsidies within the framework of current activity translated into weakening of their financial independence in the case of gminas and towns with powiat status. In conclusion, the management of operational and investment activity of LGUs is determined, among others, by their financial possibilities and development potential. Unfortunately, after 2015, both the operational and total potential for the development decreased in the units studied. In 2016, the units implemented very moderate investment policies, even though their capability of selffinancing was quite high. The revival of the investment activity occurred in 2017 due to the good financial condition of the units, debt reduction and savings at the operational level. 


\section{References}

1. Brzozowska, K., Gorzałczyńska-Koczkodaj, M., Kogut-Jaworska, M., and Zioło, M. (2017). Gospodarka finansowa w jednostkach samorzadu terytorialnego. Warsaw: CeDeWu Sp. z o.o.

2. Dylewski, M., Filipiak. B., and Gorzałczyńska-Koczkodaj, M. (2006). Finanse samorzadowe: narzędzia, decyzje, procesy. Warsaw: PWN.

3. Jastrzębska, M. (2012). Finanse jednostek samorzadu terytorialnego. Warsaw: LEX a Wolters Kluwer Business.

4. Kornberger-Sokołowska, E. (2012). Finanse jednostek samorzadu terytorialnego. Warsaw: LexisNexis.

5. Kożuch, A. (2012). Budżetowanie jako instrument zarzadzania finansami jednostki samorzadu terytorialnego. Warsaw: PWN.

6. Król, D. (2016). Ocena instrumentów zarządzania finansami samorządu terytorialnego w świetle ewolucji paradygmatu finansów publicznych. Financial Sciences, 1(26), 42-53.

7. Łukomska-Szarek, J., Zawora, J., and Kawecki, M. (2018). Metody analityczne $w$ zarzadzaniu finansami jednostek samorzadu terytorialnego. Częstochowa: PTE.

8. Satoła, Ł. (2015). Kondycja finansowa gmin w warunkach zmiennej koniunktury gospodarczej. Journal of Agribusiness and Rural Development, Vol. 1(35), 113-123.

9. Sawicka, K. (2013). Finanse samorzadu terytorialnego - podstawy wyodrębnienia, struktura. Wrocław: Prawnicza i Ekonomiczna Biblioteka Cyfrowa.

10. Sołtyk, P., and Dębowska-Sołtyk, M. (2016). Finanse samorzadowe. Warsaw: Difin.

11. Stanny, M., and Strzelczyk, W. (2018). Kondycja finansowa samorzadów lokalnych a rozwój społeczno-gospodarczy obszarów wiejskich. Ujęcie przestrzenne. Warszawa: Scholar Sp. z o.o.

12. Surówka, K. (2013). Samodzielność finansowa samorzadu terytorialnego w Polsce. Warsaw: PWE.

13. www.gov.pl/web/finance. 